Information Management and Business Review

Vol. 4, No. 7, pp. 370-378, July 2012 (ISSN 2220-3796)

\title{
Shrinking Employees Turnover Intention by applying Tools of Job Embeddedness (Used as a Mediator)
}

\author{
*Faiz Ullah Khattak ${ }^{1}$, Amjad Hussain ${ }^{1}$, Qaiser Mehmood ${ }^{2}$, Aamir Mumtaz ${ }^{1}$, Ijaz Ur Rehman ${ }^{1}$, Kashif Ur Rehman ${ }^{1}$ \\ ${ }^{1}$ Iqra University Islamabad, Pakistan \\ ${ }^{2}$ Muhammad Ali Jinnah University Islamabad, Pakistan \\ *faiz.khattak1983@gmail.com
}

\begin{abstract}
The current research study examined the association among the HRM practices through job embeddedness (as a mediator) and employee turnover intentions. In this study, the researchers used new construct i.e. job embeddedness to explore its mediating impact on the relationship between employee turnover intentions and HRM practices such as training, compensation, career planning, performance appraisal and supervisor support. Job embeddedness was studied in terms of fit, links, and sacrifice organization. Job embeddedness plays a crucial role to reduce turnover. If organization applies these HRM practices in true letter and spirit, then their employees will be more satisfied, committed, and loyal to that organization. If employees are more embedded to the organization in a positive manner, so that employees are more committed, satisfied and impacts their performance.
\end{abstract}

Keywords: HRM practices, Employee turnover intentions, Employee behavior, Job embeddedness

\section{Introduction}

The effectiveness talent management mechanism's arrangement is vital for any organization. The organization always depends upon on the human capital for smooth operation and execution. According to Pfeffer (1994) stated that the developing of human capital is competitive advantages for firms' values. Talented employees' retention is critical task for any organization. Many organizations' are busy to find the right talent, after recruitment \& selection and the second phase to retain the high caliber employees by reducing the turnover ratio of the organization. To retain the efficient and effective employees are most important task for the organization and use the retention strategies of their competitors. Most of research studies show that turnover intentions are associated with service climate, reaction to the job and decide to stay or quit from the job. Not only financial cost associated with turnover, some other costs that are not visible to management, it may also disturb the social networks and decrease satisfaction, motivation, loyalty and commitment in the remaining employees of the organization (Mobley, 1982; Staw, 1980). This is important question for the researchers and HR practitioners that, "Why does an employee quit from the organization?" and "Why does they stay there?" Apart from that, these questions are different from each other, over the years; partial answers to these questions have been developed by researchers (Mitchell et al., 2001). In general thinking the people who are more satisfied with their jobs, motivated, punctual, and loyal to the institution/organizations otherwise quit if not satisfied. However, many of research studies show that work like behavior and attitude can play very small level role in the individuals' quitting and retention (Griffeth, Hom \& Gaertner, 2000; Hom \& Griffeth, 1995). Maertz \& Campion (1998) have studied and contributed that apart from Job motivation, job gratification, organizational loyalty are factors that are essential for knowing turnover. Besides financial factors, many non-financial and non-attitudinal factors will keep retain individual in workplace due to social networks and bound with organizational environment (Mitchell et al., 2001). A new approach added to this study for decreasing the turnover is the employing tool of Job embeddedness. In the latest research on socialization (Cable \& Judge, 1996; Cable \& Parsons, 1999) proposed that work and organization fitness may be greatly related to socialization systems. Researchers studied and contributed that preciseness might be restrained the relation between embeddedness and turnover (Barrick \& Mount, 1996; Chan, 1996). Mitchell et al. (2001) has constructed and developed the new concept of job embeddedness. As per the new concept of job, involvement (embeddedness) is applied to investigate what factors cause to retain employees and keeps them bound/embedded with organization. We 
are located in the era where businesses are increasing day by day. Therefore, the turnover is one of the serious and considerable issues in Pakistani setting; in this study, we are applying a concept of embeddedness to retain the talented employees. Job embeddedness is used as mediator in the ongoing research, to mediate the association between human resource management process and worker's turnover intentions.

\section{Research background and Hypothesis}

Most of experimental and conceptual research papers are depended on March and Simon's (1958) research works. Job related behavior, attitude, and perceived desirability of movement coerce employee to seek a new job. Employee turnover has been explained and predicated by the psychological school. Further added that the departure of employees have been used (absenteeism, organizational attachment and social network), wherever departure of employees are anticipated to regularly guide to turnover by taking steps. To explain the reasons of turnover intentions of employees depend upon individual-level factors, like personal preference, attachment and involvement and organizational-level factors, like HRM systems (Deutsch, Langton, and Aldrich, 2000). Individual-level factors means that people are different from each other in many ways, therefore investigating the method which is used by job holder to choose other potential employment opportunity (Deutsch et al., 2000; Lee \& Mitchell, 1994). (Brayfield \& Crockett, 1955; Mobley et al., 1979; Price, 1977; Vroom, 1964) have studied and contributed that peoples are quitting from one job to other to get their desired level of job satisfaction. Most of researchers and HR practitioners contributed that the employment association is basic fluctuations that have effects on satisfaction, retention, and attraction of brilliant workers (Horwitz, Hing \& Quazi, 2003; Roehling, Cavanaugh, Moyhihan \& Boswell, 2000; Turnley and Feldsman, 2000). The rapid changing in economy of the world, due to progression towards the international markets, globalization, international competitors; organizations are required to be elastic and should enhance their output level. It will enhance the job insecurity of the workers at every stage of the institutions (King, 2000). It important task for the HR manager to appeal and keep the talented employees, who have abilities/capabilities that are very crucial for the organization existence (Horwitz et al., 20003; Mitchell, Holtom \& Lee, 2001; Steel, Griffeth \& hom, 2002). To retain the talented employee of the organization has become very important concept to scrutinize the set of HRM system used by organization in order to minimize the turnover ratio (Mitchell et al., 2001; Steel et al., 2002).

The individuals based relationships and links with other people or activities is the name of job embeddedness, in other words, their job and community are linked with their life, so these links and relationships can be broken when any employee quit from a job (Mitchell et el., 2001). Embeddedness means that how much economic affairs are disturbed by social networks (Granovetter, 1985). Mitchell et al. (2001) have further discussed the term job embeddedness and develop some points that the individual as a part of social network of relationships and connections. The individual's life is the association of many social webs, in which individual are connected with each other. In this study, we will focus on individual-level factors, by examining the turnover intentions through applying a tool of job embeddedness on workers who wants to job somewhere else. Job embeddedness is latest concept, which is developed by Mitchell et al. (2001). Mitchell further added that influence the worker's decision whether to remain or quit from the present job and other words; a social network or web in which an employee becomes bound. The concept of job embeddedness has been evolved from Lewin's (1951) and from the embedded figures and field theories (Witkin et al., 1977). The peoples are linked through many connections, relationship within their backgrounds and environment by embedded figures (Mitchell et al., 2001). Following are the important characteristics of job embeddedness:

- Degree in which job and society are similar;

- Links with people, team and community

- The person would sacrifice if he/she changing jobs.

The above parts are very important within organization (on the job) and outside the organization (community). In this paper job, embeddedness is used to mediate the relationships between organizations (on the job) and community level (off the job) aspects and to retain the talented workers. It shows that there are many other reasons why employee continues the present job. Therefore, the effect of on the newly developed concept in the existence of employee level factors would lead to separation, the awareness in the 
organization regarding HRM practices has not been judged. Allen, Shore, and Griffeth, (2003) have studied and contributed that human resources practices are the positive signal for employees' development and negative signal for employees' turnover. Number of variable have been developed and construct which have impact on employee turnover intentions. In this study, we will discuss the HR practices such as reward/compensation, training, supervisor support, and career planning and performance appraisal through using job embeddedness as a mediator, to explore the turnover intention.

Training: Training is the one of most impartment element of human resource practices. Through training we can easily improving, enhancing and modifying employees, knowledge, abilities, competency level and prepare for the existing and upcoming/job assignment to resolve the problems in efficient manner. Training is also play important role in employee retention as well as organizational growth and performance. According to the Commonwealth Fund, (1993) argued that Training is considering one of the important factors of retention and enhancing the opportunity of training is crucial task for retaining employees. To get better performance from the employees in the organizations they are trained. Training is categories in two ways; one is explicit and other is common training (Filipe \& Karen, 2004). Training is considering an important factor of employee retention and the accessibility of training is significant for retaining mature employees (Marjorie \& Andrew, 2003). Jacqui, (2004) concentrated on the employees training concerning communication abilities. According to Shaw et al. (1998) argued that an important role is played by training in the maintenance and development of organizational commitment. The above HR practice can increase the attachment of employee with organization and enhance retention. Job embeddedness concept is used as mediator, where training should enhance the fit between the employee and job, therefore it also showed that a sacrifice must be related to experience if employee decide to leave job (Mitchell et al., 2001). Therefore the training cannot positively relate with turnover intentions.

Compensation: Compensation is the process of both direct and indirect compensation is to increase employee commitment, loyal, satisfaction, and association to the institution/organization (Appelbaum, Berg, and Kalleberg, 2000; Arthur, 1994). Most of research studies shows that the negative association between high packages or pay satisfaction and employee separation (Leonard, 1987; Powell, Montgomery, and Cosgrove, 1994; Shaw et al., 1998). According to (Trevor, Barry, and Boudreau, 1997) stated that smart salary packages has considerably decrease turnover for better employees performance. If organization can fair performance evaluation system, then high performing employees who were well compensated and rewarded (performance base pay) on the basis of performance were less probably to leave the job as well as to those who are lower performer (Park., Ofori-Dankwa, and Bishop, 1994; Williams \& Livingstone, 1994). It shows that organization may improve their employee retention by increasing their career planning opportunity.

Performance Appraisal: Performance appraisal is a method in organizations to facilitate mounting people by way of generating greater responsiveness of what they do and how they do. A huge amount of study has been conducted on supervisory rating of employee job performance, with much of this research focusing on factors that bias performance rating (Murphy \& Cleveland, 1991). Accountability theory provides a theoretical framework for understanding effect of self appraisal on supervisory performance evolutions. The basic premise of accountability theory is that in order to maintain self-esteem, people seek approval from others to home they feel accountable (Tetlock, 1985).

Supervisory Support: According to the public support, supervisory support has worked in two ways. Firstly, it has a straight effect, with the accomplishment of individual requirements and the encouragement of fitness and joy, which clearly reduce the unenthusiastic pressure of job force. Next, it has a buffering consequences, sense that public help could contribute an intervening part to relieve work stress. The effect of work force, public support ultimately generates an optimistic result on physical and psychological fitness and in general life change (House, 1981). As related to problem-solving at workplace setting, support from colleague, partners and family is less helpful than supervisor suggestion and supervisor support plays a vital role to motivate subordinates. Social acknowledgment from managers, for instance, respects and support, can assist to relieve work-family conflicts (Argyle \& Furnham, 1983). Beehr (1985) also good supervisions, assist, and sustain. Many studies reveals that a supervisory support can enhance a worker's job achievement, 
commitment, satisfaction, performance, and loyalty through concerning to the worker's work-family clashes (Carlson \& Perrewe, 1999; Schmelz \& Ramsey, 1997).

Career Planning: Career planning is play important role in career management. The information required for the assessments of employees performance, succession plans, career development programs, career counseling, mentoring, career development, and management training. For example, if organizations provide clear information to employees about career growth then employees will be more motivated and satisfied from the present job. According to Ladkin and Riley, (1999, p. 226) explained that the career planning and development of individual as well as organization can influenced by a number of factors. McMahon \& Patton, (1995 p. 16) studied and contributed that an employee career planning is affected by a number of diverse and complex factors, like age, gender, education, societal and environment etc. Arthur, Hall, and Lawrence, (1989, p. 9) argued and described that the term career "the developing series of a individual's job experiences over time," and becomes a conventional explanation of career nowadays (Dries Dries, Pepermans, and Carlier, 2008; Khapova \& Korotov, 2007). Job embeddedness (Used as a Mediator). Keeping in the view, the above aforementioned variables have negative influence on employee turnover intentions. So here we use job embeddedness as mediator to mediate this relationship. According to Holtom, Mitchell, and Lee, (2006) contributed that job embeddedness is new construct which impacts on the employees perception to continue the job or quit from the present job. Mitchell et el. (2001) have studied and contributed that the job embeddedness is divided in further three sub dimension which are, on the job (organization) aspects and off the job (community) aspects such as links, fit and scarifies. These three dimensions can also be expended on the bases of on the job and off the job into six facets such as links organization (relationship with coworkers), fit organization (fit with organization regarding skills and job demands), scarifies organization (organization sponsored and community based services activities) -On the job factors, links community (personal relationship), fit community (family relationship), and scarifies community (community commitment)-Off the job. In this study we focuses on the job factors of embeddedness, therefore, this study relate to organization (HRM practices) are explored and other side community based factors (off the job) are not relevant to this study. We know that an individual can becomes bound in a career in different manners connected to both organization ad communities. However here we discussed only on the job (organization) factors of job embeddedness.

Fit Organizations: Fit can be defined as "an employee feels easy and relaxed with in his job, organization, and environment" (Holtom et al., 2006). According to the concept of job attachment (embeddedness), an individual personal value, growth, career opportunity/advancement, and their plans for future growth should "fit" and related to the interest of business culture and the demands of his/her present job (employee skills, information, \& competency level of employee etc). The concept of job embeddedness can be defined as organization can select a suitable candidate (the better the fit), probably the individual will consider personally as well as professionally attached to the institution/organization. If organization is failed to provide the perfect/fit environment to their employees and it will also increase the turnover intentions (Chatman, 1991). The personal characteristic of employees fit with a job may decrease turnover (Chan, 1996). Villanova et al. (1994) also studied and argued that lack of job capability expected turnover. As a result, an individual suitable with job and institution affects his/her connection to the job and organizations.

Links Organizations: Holtom et al. (2006) argued that links are official or unofficial associations between individual and organization or other people. Links can be signal of connection that an individual connect with subordinates, managers, team member, friends, organization, family and physical environment, where he/she is working. As per the Mitchell et al. (2001) described that the huge number of connections and social network, the employee is socially attached to the work and organization. A number of research study shows that an individual is stay in the job due to pressure form the colleague and team member (Meartz el al., 1996; Prestholdt, Lane, and Mathews, 1987). According to Abelson, (1987) suggests that the links and social web and relationship of employee will increase the employee job duration and reduce the individual intention to work somewhere else.

Sacrifice Organization: Sacrifice means that when employee giving up by leaving the present job may be sacrifice perceived cost of substance and psychological benefits (Mitchell et al., 2001). When leaving some job 
the following personal losses may occurred such as losing friends, colleagues, subordinates, supervisors, interesting projects and financial benefits etc. Shaw et al. (1998) studied and contributed that it is very difficult and tough job for employee to leave the organization or break services with the institution such as financial and non financial benefits such as reserve/stock or pension benefits as well as potential sacrifice to quit from the job or organization like opportunity for job safety and career growth. Similarly, those employees who stay in the organization or job, they will find various kinds of advantages like compensation, career growth, financial benefits, and other nonfinancial benefits as compared to those individuals who leave the job and giving up the above advantages. When an organizations can follow the HRM practices in true manner and sprit and also care about employee social networks, employees should be bound in the organizations, For example the higher investment on training, fair performance appraisal and evaluation procedure, higher the career growth/opportunity and higher compensation and reward system helps individual fit in their job and organization also. The better relationship between supervisor and subordinate may also help to fit in the job and organizations. The links, fit and sacrifice also contribute to increase employee job embeddedness. Keeping in view the literature, it means that human resource practices would have significant impact on an individual's job embeddedness.

\section{From the above literature, we derived the following hypothesis}

H1. Training and turnover are negatively correlated, which also mediated by job embeddedness.

H2. The association between compensation and turnover intention are negatively correlated, which also mediated by Job embeddedness.

H3: The negative association exists between supervisory support and turnover, which is mediated by job embeddedness.

H4. The association between performance appraisal and turnover intention are negatively correlated, which also mediated by job embeddedness.

H5. The association between career planning and turnover intention are negatively correlated, which also mediated by job embeddedness.

\section{Theoretical Model}

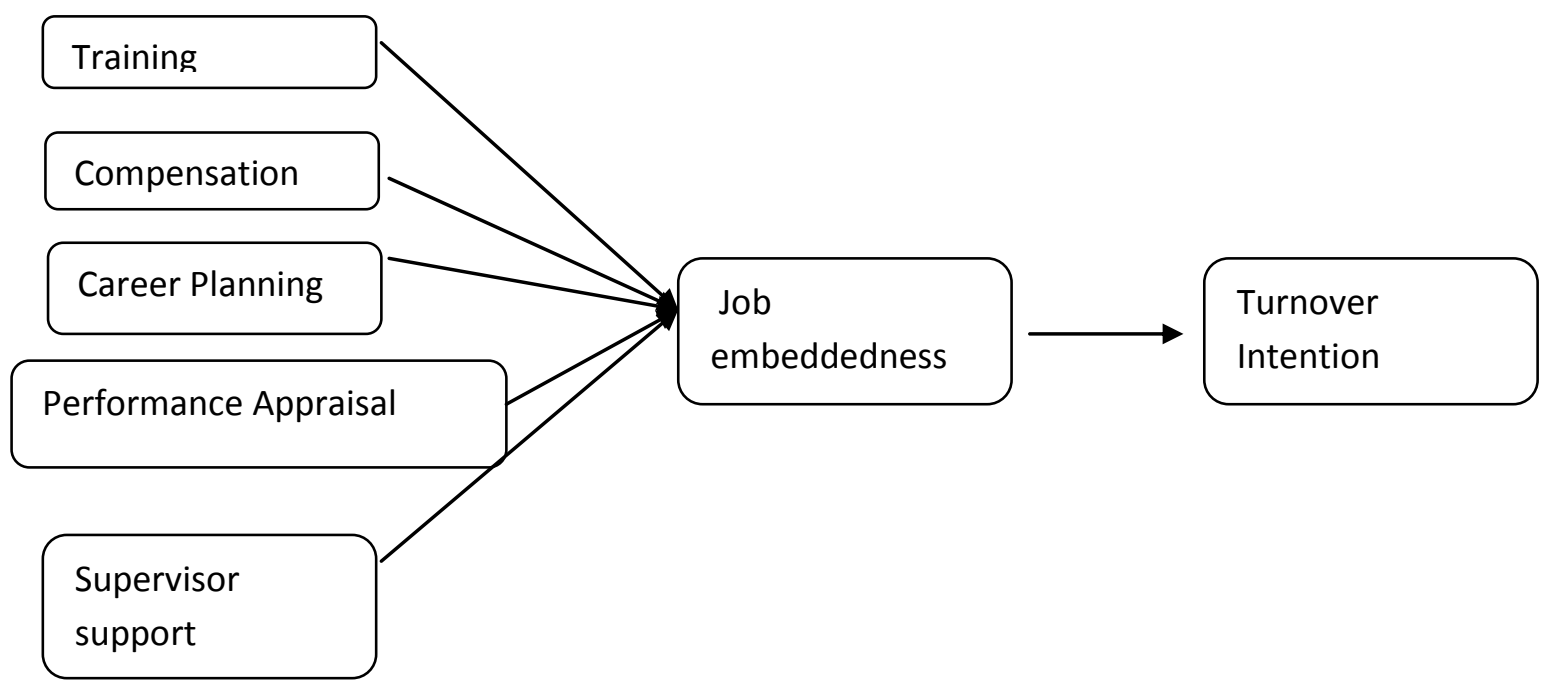

\section{Discussion}

The present research investigated and highlighted the issue of employee's turnover intentions. In this study, the concept of job embeddedness was used to explore and enlighten the connection between HRM practices and worker's turnover intention. According to Allen et al. (2003), concluded that little research work has been carried out to check how much HRM practices impact on employee turnover decision. From the 
literature survey, concluded that overall all HRM practices are negatively associated with employee's turnover decision, which is also mediated by job embeddedness. From the literature, it is also found that compensation is only factor, which is also influenced by job embeddedness in the connection to worker's turnover intention. Consequently, if any employee thanking to quieting from the present job than the employees will also thanking about the material benefits which attached with current job that he/she has to sacrifice. It has also found from the literature, the supervisor support is also mediated by job embeddedness. Furthermore if employee enjoyed a good relationship with supervisor and other colleagues, if he/she is quieting from the present organization then he/she will lose all these (interpersonal, intrapersonal and respect etc). This suggests that the individual will must attached in their jobs when he/she receive more help and kind cooperation from the managers and colleagues. Career planning is negatively associated with turnover. If organization provides more career opportunity to their employees, this relationship is also mediated by job embeddedness. Therefore, if organization provides more opportunity to their employees for grooming, promoting and compensated well, the employees will be more motivated and embedded with the present job. Furthermore, performance appraisal is also negatively linked with employee's turnover intentions. If employees are evaluated regularly and fair, evaluation has been carried out. Based on fair evaluation, the employees will compensated with both financial and nonfinancial rewards. It would be a sacrifice for individuals to quiet from the organization, which offers fair performance appraisal system. Therefore, an individual will be more attached/connected with his/her jobs and less likely to leave, if fair performance appraisal system exists.

Further move to training, training is not mediated/intervene by job embeddedness. Consequently, training is clearly linked to worker's intention to quiet. If employees are provided training facility and become trained, then he thank about to quieting because more opportunities are available in the market for well-trained people. According to (Lynch, 1991) stated that training may provide opportunities to quiet their current jobs. Sometimes, training will retain best employees, because they knows that this kind of training facility is not available in other organization, if he/she will quiet from this job then he/she will sacrifice training facility. Previous research stated that training might help organizations to retain their employees (Hequet, 1993). The finding of the current study does not support the positive impact of training on retaining employees and does not support the concept teat training helps attached (embedded) employees in their jobs. The previous research reveals that the training and employees turnover intentions are negatively linked with each other. This finding is exactly what we expected and is consistent with previous research (Allen et al., 2003; Hom \& Griffeth, 1995; Bennett et al., 1993). The findings of the current study have several practical implications. The mangers must be well aware from all the HRM practices and must used in fair way in their organization. The management staff needs have to be knowledge about only HRM systems may not directly affect employees' turnover decision, some others practices create the links, fit and sacrifice that attached (embedded) employees in the current job and restrain them from quieting the present organization. Furthermore, based on the three factors of job embeddedness, managers must watched and used a variety of HRM process to create a strong association, links, fits and sacrifices (in term of financial and non financial) for employees who search and thank about to quiet from the present job/position or organization.

\section{Conclusion}

In fact, most of the organizations did not use the human resources practices and the new concept of job embeddedness in true letter and spirit, in order to retain the most competent employees of the organizations. Therefore, the proposed model suggest that HRM practices and job embeddedness can decrease the turnover and also increase the performance and satisfaction level of the employees which automatically decrease the financial burden of the organization that occurs on the recruitment and selection, training and development etc. The new concept of job embeddedness and HRM practices build a culture to make them embed into their jobs retain from quitting the organization. 


\section{References}

Abelson, M. A. (1987). Examination of avoidable and unavoidable turnover. Journal of Applied Psychology, 72, 382-6.

Allen, D. G., Shore, L. M. \& Griffeth, R. W. (2003). The role of perceived organizational support and supportive human resource practices in the turnover process. Journal of Management, 29, 99-118.

Appelbaum, E., Berg, P. \& Kalleberg, A. (2000). Balancing work and family: effects of high-performance work systems and high-commitment workplaces. Report to the US Department of Labor, Washington, DC.

Argyle, M. \& Furnham, A. (1983). Sources of satisfaction and conflict in long-term relationships. Journal of Marriage and the Family, 45, 481-93.

Arthur, M. B., Hall, D. T. \& Lawrence, B. S. (1989). Handbook of Career Theory. Cambridge University Press, Cambridge.

Arthur, J. (1994). Effects of human resource systems on manufacturing performance and turnover. Academy of Management Journal, 37, 670-87.

Barrick, M. R. \& Mount, M. K. (1996). Effects of impression management and self-deception on the predictive validity of personality construct. Journal of Applied Psychology, 81, 261-272.

Bartlett, K. R. (2001). The relationship between training and organizational commitment: a study in the health care field. Human Resource Development Quarterly, 12,335-52.

Beehr, T. A. (1985). The role of social support in coping with organizational stress. In Beehr, T.A. and Bhagat, R.S. (Eds), Human Stress and Cognitions in Organizations, Wiley, New York, NY.

Bennett, N., Blume, T. C., Long, R. G., \& Roman, P. M. (1993). A firm-level analysis of employees' attrition. Group \& Organization Management, 18(4), 482-99.

Brayfield, A. H. \& Crockett, W. H. (1955). Employee attitudes and employee performance. Psychological Bulletin, 52, 396-424.

Cable, D. M. \& Judge, T. A. (1996). Person-organization fit, job choice decision, and organizational entry. Organizational Behavior and Human Decision Processes, 67, 294-311.

Cable, D. M. \& Parsons, C. K. (1999). Establishing person-organization fit during organizational entry. Paper presented at the Annual Meetings of the Academy of Management, Chicago, IL.

Capelli, P. (2001). A market driven approach to retaining talent. Harvard Business Review on finding and keeping the best people (27-50). Boston: Harvard business school press.

Carlson, D. S. \& Perrewe, P. L. (1999). The role of social support in the stressor-strain relationship: an examination of work-family conflict. Journal of Management, 25(4), 513-40.

Chan, D. (1996). Cognitive misfit of problem-solving style at work: A facet of person organization fit. Organizational Behavior and Human Decision Processes, 68, 194-207.

Chatman, J. A. (1991). Matching people and organization: selection and socialization in public accounting firms. Administrative Science Quarterly, 36, 459-84.

Deutsch, S., Langton, N. \& Aldrich, H. (2000). Should I stay or should I go? Voluntary turnover in small firms. Working paper, University of North Carolina.

Dries, N., Pepermans, R. \& Carlier, O. (2008). Career success: constructing a multidimensional model. Journal of Vocational Behavior, 73(2), 254-67.

Filipe, A. S. \& Karen, M. (2004). Employee Training and Wage Compression in Britain. Discussion Paper No. 1197 June 2004.

Granovetter, M. (1985). Economic action and social structure: The problem of embeddedness. American Journal of Sociology, 91, 481-510.

Griffeth, R. W., Horn, P. W. \& Gaertner, S. (2000). A meta-analysis of antecedents and correlates of employee turnover: update, moderator tests, and research implications for the millennium. Journal of Management, 26, 463-88.

Hequet, M. (1993). Can training stop turnover? Training, 30, 82-7.

Hom, P. W. \& Griffeth, R. W. (1995). Employee Turnover, South/Western, Cincinnati, OH. Hutchison, S. (1997), 'A path model of perceived organizational support. Journal of Social Behavior and Personality, 12,15974.

Holtom, B. C., Mitchell, T. R. \& Lee, T. (2006). Increasing Human and Social Capital by applying job embeddedness Theory. Organizational Dynamics, 35(4), 316-331. 
Horwitz, F. W., Heng, C. T. \& Quazi, H. A. (2003). Finders, Keepers? Attracting, Motivating, and Retaining Knowledge Workers. Human Resource Management Journal, 13(4), 23-44.

House, J. S. (1981).Work Stress and Social Support, Addison-Wesley, Reading, MA.

Khapova, S. N. \& Korotov, K. (2007). Dynamics of Western career attributes in the Russian context. Career Development International, 12(1), 68-85.

King, J. E., (2000). White-collar reactions to job insecurity and the role of the pshyclogical contract: Implications for Human Resources Management. Human Resource Management, 39(1), 79-92.

Ladkin, A. (1999). Life and work history analysis: the value of this research Method for Tourism and Hospitality. Tourism Management, 20, 37-45.

Lee, T. W. \& Mitchell, T. R. (1994). An alternative approach: the unfolding model of voluntary employment. The Academy of Management Review, 39, 5-36.

Leonard, J. S. (1987). Carrots and sticks: pay, supervision, and turnover. Journal of Labor Economics, 5,136-52.

Lewin, K. (1951). Field Theory in Social Science, Harper, New York, NY.

Lynch, L. M. (1991). The role of off the job versus on-the-job training for the mobility of women

Workers. American Economic Review, Papers and Proceedings, 81, 151-6.

Maertz, C. P. \& Campion, M. A. (1998). 25 years of voluntary turnover research: a review and critique, in Cooper, C.L. and Robertson, I.T. (Eds). International Review of Industrial and Organizational Psychology, 13, 49-81.

Maertz, C. P., Stevens, M. J., Campion, M. A. \& Frenandez, A. (1996). Worker turnover in Mexican factories: a qualitative investigation and model development. Paper presented at the annual at the Academy of Management, Cincinnati, $\mathrm{OH}$.

March, J. G. \& Simon, H. A. (1958). Organizations. New York: John Wiley.

Marjorie, A. S. \& Andrew, T. (2003).The Demographic Time-Bomb of Aging Employees: How are HR Professionals Responding?" published in the H R Professional (formerly: Human Resources Professional (Naylor Communications, Canada - ISSN: 0847-9453), October/November, 41-42.

McMahon, M. \& Patton, W. (1995). Development of a systems theory of Career development. Australian Journal of Career Development, 3, 15-20.

Mitchell, T. R., Holtom, B. C., Lee, T. W., Sablynski, C. J. \& Erez, M. (2001). Why people stay: using job embeddedness to predict voluntary turnover. Academy of Management Journal, 44, 1102-1122.

Mitchell, T. R., Holtom, B. C. \& Lee, T. W. (2001). How to keep your best employee: Development an effective retention policy. Academy of management Executive, 15(4), 96-109.

Mobley, W. H. (1982). Employee turnover, causes, consequences, and control. Reading, MA: Addison-Wesley.

Mobley, W. H., Griffeth, R. W., Hand, H. H. \& Meglino, B. M. (1979). Review and conceptual analysis of the employee turnover process. Psychological Bulletin, 86(3), 493-522.

Murphy, K. R. \& Cleveland, J. N. (1991). Performance Appraisal: An Organizational Perspective. Boston: Allayn Bacon.

Park, H. Y., Ofori-Dankwa, J. \& Bishop, D. R. (1994). Organizational and environmental determinants of functional and dysfunctional turnover: practical and research implications. Human Relations, 47(3), 353-66.

Pfeffer, J. (1994). Competitive advantage through people: Unleashing the power of the work force. Boston: Harvard Business School Press.

Prestholdt, P. H., Lane, I. M. \& Mathews, R. C. (1987). Nurse Turnover as reasoned action: development of a process model. Journal of Applied Psychology, 72, 221-7.

Price, J. (1977). The Study of Turnover, Iowa State University Press, Ames, IA.

Powell, I., Montgomery, M. \& Cosgrove, J. (1994). Compensation structure and establishment quit and fire rates. Industrial Relations, 33(2), 229-48.

Roehling, M. V., Cavanaugh, M. A., Moyninan, L. M. \& Boswell, W. (2000). The nature of the new employment relationships: A content analysis of the practitioner and academic Literatures. Human Resource Management, 39(4), 305-320.

Schmelz, D. R. \& Ramsey, R. P. (1997). Considering sources and types of social support: a psychometric evaluation of the House and Wells (1978) instrument. Journal of Personal Selling \& Sales Management, 12, 49-61.

Shaw, J. D., Delery, J. E., Jenkins, G. D. \& Gupta, N. (1998). An organization-level analysis of voluntary and involuntary turnover. Academy of Management Journal, 41, 511-525. 
Staw, B. M. (1980).The Consequences of turnover. Journal of Occupational Behavior, 1, 253-73.

Steel, R. P., Graffeth, R. W. \& Hom, P. W. (2002). Practical retention policy for the practical manager. $A n$ academy of Management Executive, 18(2), 149-169.

Tetlock, P. E. (1985). Accountability: The neglected social context of judgment and choice. In B.M Staw and L.L. Cummings (Eds.), Research in organizational behavior, 7(2).

The Commonwealth Fund. (1993). The Untapped Resource: The Final Report of the Americans Over 55 at Work Program, the Commonwealth Fund, and New York, NY.

Trevor, C. O., Barry, G. \& Boudreau, J. W. (1997). Voluntary turnover and job performance: curvilinearity and the moderating influences of salary growth and promotions. Journal of Applied Psychology, 82(1), 4461.

Turnley, W. H., Feldman, D. C. (2000). Re-examining the effects of psychological contract violations: Unmet expectations and job dissatisfaction as mediators. Journal of organizational behavior, 21(1), 25-42.

Jacqui, H. (2004). Presentation skills. Industrial and Commercial Training, 36(3), 125-127.

Vroom, V. H. (1964). Work and Motivation, Wiley, New York, NY.

Witkin, H. A., Moore, C. A., Good, E. D. A. \& Cox, P. W. (1977). Field-dependent and field independent cognitive styles and their educational implications. Review of Educational Research, 47, 1-64.

Williams, C. \& Parrack, L. L. (1990). Another look at the relationship between performance and voluntary turnover. Academy of Management Journal, 37, 269-98. 